\title{
The Past Present and the Future of Coronary Arterial Lesions with a Non- Ischemic Fractional Flow Reserve (FFR 0.80 and Above)
}

\section{Mallikarjuna MRE*}

Department of Cardiology, University of Arkansas for Medical Sciences, USA

*Corresponding author: Mallikarjuna MRE, Department of Cardiology, University of Arkansas for Medical Sciences, USA, Tel: 501-686-7438; E-mail: mmedupuganti@gmail.com

Received date: April 08, 2016; Accepted date: April 08, 2016; Published date: April 16, 2016

Copyright: (c) 2016 Mallikarjuna MRE. This is an open-access article distributed under the terms of the Creative Commons Attribution License, which permits unrestricted use, distribution, and reproduction in any medium, provided the original author and source are credited.

\section{Editorial}

Coronary artery disease is major cause of morbidity and mortality $[1,2]$; it accounts for $1 \%$ of all visits to the general practitioner $[3,4], 5 \%$ of all emergency department visits and $40 \%$ of all admissions [5]. In 2010 CVD accounted for $31.9 \%$ off all deaths [6]. In the same time period coronary heart disease (CHD) caused approximately 1 of every 6 deaths in the United States [6]. An estimated 620000 Americans have a new coronary attack every year and 295000 will have a recurrent attack each year [6]. An additional 150000 silent first myocardial infarctions occur each year [6]. 1 American has a coronary event every $34 \mathrm{~s}$ and an American will die from CHD every $1 \mathrm{~min} 23 \mathrm{~s}$ [6].

The first selective coronary angiogram was performed when Dr F. Mason Sones Jr. when he inadvertently engaged the right coronary artery on October 30, 1958 [7]. Since then we have come a long way riding on the shoulder of giants such as Melvin Judkins and others [8]. We soon realized that coronary angiography alone cannot determine the physiological significance of stenosis.

Pijlis et al. validated fractional flow reserve (FFR) by studying 45 patients with an intermediate coronary stenosis with bicycle exercise testing, dobutamine echocardiography, thallium scintigraphy and quantitative coronary angiography. The results on the above tests were compared with the measured fractional flow reserve [9]. The sensitivity, specificity, positive and negative predictive values of a FFR value of 0.75 were determined to be $88 \%, 100 \%, 100 \%$ and $88 \%$ respectively. FFR value of less than 0.75 was associated with myocardial ischemia and a value of more than 0.80 was non ischemic, FFR values in between were considered borderline [10].

Outcome studies that followed determined the natural history of borderline and non-ischemic lesions. Studies on borderline lesions showed that such lesions have a poor prognosis in the absence of revascularization [11-13]. The current FFR threshold for intervention is 0.80 based on the results from FAME [14,15]. Finally many wellknown trials demonstrated that deferred lesions have an excellent long term prognosis [16-18]. However recent trials questioned the wisdom of deferring all lesions with an FFR above 0.80 [19-21].

The answer to these discrepancies probably lies in understanding the role of coronary microvascular resistance. An exhaustive discussion of invasive assessment of coronary physiology is beyond the scope of the current discussion, briefly in a normal vessel FFR and coronary flow reserve (CFR) should be normal and index of microcirculatory resistance (IMR) should be low [22]. Isolated epicardial stenosis leads to a lowering of FFR, CFR and IMR [22] When diffuse atherosclerotic narrowing is superimposed on a focal epicardial stenosis the FFR can be falsely normal however the IMR and CFR will both be low [22]. When focal stenosis and microcirculatory dysfunction coexist both FFR and IMR will be elevated but CFR will be low [22]. Hence FFR can be normal inspite of a significant epicardial stenosis [22]. A high IMR has been shown to play an important role in heart failure $[23,24]$, in smokers [25] and in those with acute coronary syndrome $[26,27]$.

Although IMR is the most important factor contributing to the discrepancy it is possible that there are at least 2 other factors that may play a role. The first is the ability of the myocardium to adapt to ischemia $[28,29]$. It makes intuitive sense that a lesser degree of flow reduction may suffice to produce ischemia in the presence of preexisting myocardial pathology that limits the ability to adapt to ischemia. Finally the acuity of onset of the ischemic insult is also important. It is likely that a permutation and combination of these three factors play a role in conditions such as heart failure [23,24], in acute coronary syndromes [26,27], in those with a H/O previous MI, in patients with COPD [25]. In summary the discrepancy between a nonischemic FFR and adverse clinical outcomes can be explained by the presence of a high microcirculatory resistance, other factors that probably play a role include the ability or lack thereof of the myocardium to adapt to ischemia and the acuity of the ischemic insult.

These factors should be addressed in future trials that study outcomes in non-ischemic coronary lesions. If it is proven that such factors play an important role, it will lead to a paradigm shift in the way we approach coronary physiology in the cardiac catheterization laboratory.

\section{References}

1. Montalescot G, Sechtem U, Achenbach S, Andreotti F, Arden C, et al. (2013) 2013 ESC guidelines on the management of stable coronary artery disease: The Task Force on the management of stable coronary disease of the European Society. Eur Heart J 34: 2949-3003.

2. Fihn SD, Gardin JM, Abrams J, Berra K, Blankenship JC, et al. (2012) 2012 ACCF/AHA/ACP/AATS/PCNA/SCAI/STS guideline for the diagnosis and management of patients with stable ischemic heart disease: a report of the American College of Cardiology Foundation/American Heart Association Task Force on Practice Guidelines, and the American College of Physicians, American Association for Thoracic Surgery, Preventive Cardiovascular Nurses Association, Society for Cardiovascular Angiography and Interventions and Society of Thoracic Surgeons. Circulation 126: e354-471.

3. Ruigómez A, Rodríguez LA, Wallander MA, Johansson S, Jones R (2006) Chest pain in general practice: incidence, comorbidity and mortality. Fam Pract 23: 167-174.

4. Nilsson S, Scheike M, Engblom D, Karlsson LG, Mölstad S, et al. (2003) Chest pain and ischaemic heart disease in primary care. Br J Gen Pract 53: 378-382.

5. Murphy NF, MacIntyre K, Capewell S, Stewart S, Pell J, et al. (2004) Hospital discharge rates for suspected acute coronary syndromes between 1990 and 2000: population based analysis. BMJ 328: 1413-1414. 
Citation: Mallikarjuna MRE (2016) The Past Present and the Future of Coronary Arterial Lesions with a Non-Ischemic Fractional Flow Reserve (FFR 0.80 and Above). J Health Med Inform 7: e139. doi:10.4172/2157-7420.1000e139

Page 2 of 2

6. Go AS, Mozaffarian D, Roger VL, Benjamin EJ, Berry JD, et al. (2014) Heart Disease and Stroke Statistics-2014 Update A Report From the American Heart Association. Circulation 129: e28-e292.

7. Geddes LA, Geddes LE (1993) The Catheter Introducers. IL: Mobium Press, Chicago 38-39.

8. Cowley MJ (2005) Tribute to a Legend in Invasive/Interventional Cardiology: Melvin P Judkins MD. (1922-1985) Society for Cardiovascular Angiography and Interventions.

9. Pijls NH, De Bruyne B, Peels K, Van Der Voort PH, Bonnier HJ, et al. (1996) Measurement of fractional flow reserve to assess the functional severity of coronary-artery stenosis. N Engl J Med 334: 1703-1708.

10. Pijls NH (2004) Optimum guidance of complex PCI by coronary pressure measurement. Heart 90: 1085-1093.

11. Adjedj J, De Bruyne B, Floré V, Di Gioia G, Ferrara A, et al. (2016) Significance of Intermediate Values of Fractional Flow Reserve in Patients with Coronary Artery Disease. Circulation. 133: 502-508.

12. Li J, Rihal CS, Matsuo Y, Elrashidi MY, Flammer AJ, et al. (2013) Sexrelated differences in fractional flow reserve-guided treatment. Circ Cardiovasc Interv 6: 662-670.

13. Lavi S, Rihal CS, Yang EH, Fassa AA, Elesber A, et al. (2007) The effect of drug eluting stents on cardiovascular events in patients with intermediate lesions and borderline fractional flow reserve. Catheter Cardiovasc Interv 70: 525-531.

14. Tonino PA, De Bruyne B, Pijls NH, Siebert U, Ikeno F, et al. (2009) Fractional flow reserve versus angiography for guiding percutaneous coronary intervention. New Engl J Med 360: 213-224

15. Pijls NH, Fearon WF, Tonino PA, Siebert U, Ikeno F, et al. (2010) Fractional flow reserve versus angiography for guiding percutaneous coronary intervention in patients with multivessel coronary artery disease: 2 year follow-up of the FAME. J Am Coll Cardiol 56: 177-184.

16. Pijls NH, van Schaardenburgh P, Manoharan G, Boersma E, Bech JW (2007) Percutaneous Coronary Intervention of Functionally Nonsignificant Stenosis 5 Year Follow-Up of the DEFER Study. J Am Coll Cardiol 49: 2105-2111.

17. Zimmermann FM, Ferrara A, Johnson NP, van Nunen LX, Escaned J, et al. (2015) Deferral vs. performance of percutaneous coronary intervention of functionally non-significant coronary stenosis: 15 year follow-up of the DEFER trial. Eur Heart J 36: 3182-3188

18. Berger A, Botman KJ, MacCarthy PA, Wijns W, Bartunek J (2005) Longterm clinical outcome after fractional flow reserve-guided percutaneous coronary intervention in patients with multivessel disease. J Am Coll Cardiol 46: 438-442.

19. Van de Hoef TP, van Lavieren MA, Damman P, Delewi R, Piek MA, et al. (2014) Physiological basis and long-term clinical outcome of discordance between fractional flow reserve and coronary flow velocity reserve in coronary stenoses of intermediate severity. Circ Cardiovasc Interv 7: 301-311.

20. Meuwissen M, Chamuleau SA, Siebes M, de Winter RJ, Koch KT, et al. (2008) The prognostic value of combined intracoronary pressure and blood flow velocity measurements after deferral of percutaneous coronary intervention. Catheter Cardiovasc Interv 71: 291-297

21. Depta JP, Patel JS, Novak E, Masrani SK, Raymer D, et al. (2014) Outcomes of Coronary Stenoses Deferred Revascularization for Borderline Versus Nonborderline Fractional Flow Reserve Values. Am J Cardiol 113: 1788-1793.

22. Pinto EM, Escaned J, Macías E, Medina M, Gonzalo N, et al. (2013) Disturbed Coronary Hemodynamics in Vessels With Intermediate Stenoses Evaluated With Fractional Flow Reserve A Combined Analysis of Epicardial and Microcirculatory Involvement in Ischemic Heart Disease. Circulation 128: 2557-2566.

23. Neglia D, L'Abbate A (2005) Coronary microvascular dysfunction and idiopathic dilated cardiomyopathy. Pharmacol Rep 57: 151-155.

24. Camici PG (2008) Coronary Microvascular Dysfunction in Patients with Cardiomyopathies. Circulation: Heart Failure 1: 150-152.

25. Miyazaki T, Ashikaga T, Ohigashi H, Komura M, Kobayashi K, et al. (2014) Impact of smoking on coronary microcirculatory resistance in patients with coronary artery disease. Int Heart J 56: 29-36.

26. Uren NG, Crake T, Lefroy DC, de Silva R, Davies GJ, et al. (1994) Reduced coronary vasodilator function in infarcted and normal myocardium after myocardial infarction. N Engl J Med 331: 222-227.

27. Marzilli M, Sambuceti G, Fedele S, L’Abbate A (2000) Coronary microcirculatory vasoconstriction during ischemia in patients with unstable angina. J Am Coll Cardiol 35: 327-334.

28. Ghosh S, Standen NB, Galiñianes (2001) Failure to Precondition Pathological Human Myocardium. Journal of the American College of Cardiology 37: 711-718

29. Wojciechowska M, Zarębiński M, Pawluczuk P, Szukiewicz D (2015) Decreased effectiveness of ischemic heart preconditioning in the state of chronic inflammation. Med Hypotheses 85: 675-679. 